\title{
Chinese STEM College Students' Perceptions on Public English Courses and Professional English Courses: An In-Depth Interview Study
}

\author{
Xiaoyi Bing ${ }^{1, a, *},{ }^{*}$, Huizhe $\mathrm{Su}^{2, \mathrm{~b}, *}, \dagger$ \\ ${ }^{1}$ Arts, Design, \& Architecture, The University of New South Wales, Australia \\ ${ }^{2}$ College of Foreign Language, Nanjing Xiaozhuang University, Nanjing, China \\ *Corresponding author.Email:az5177056@zmail.unsw.edu.au, ${ }^{b}$ suhuizhehyc@outlook.com \\ These authors contributed equally
}

\begin{abstract}
China is facing an alternative international environment with fierce competition specifically in the STEM fields. Chinese citizens' ability to effectively use English is vital for China to succeed in participation in all international STEM-related activities. College English education in China is thus being put forward higher and more urgent requirements to meet the new challenges. However, the current setup of college English courses in China that often consists of Public English courses and Professional English courses is not preparing Chinese students, specifically STEM-majored students, for their career development and academic success at a satisfactory level. Therefore, this study conducted in-depth interview on Chinese STEM college students' perceptions on Public English courses and Professional English Courses. This study aimed at investigating the problems of the setup of college English courses, by studying STEM college students' perceptions on those courses, to provide practical recommendations for policymakers and university administrations to design appropriate English courses that could prepare college students with English proficiency to meet the new international challenges.
\end{abstract}

Keywords: component; non-English majors, STEM, college English, profession-based English class, development, in-depth interview

\section{INTRODUCTION}

China is facing an alternative international environment with fierce competition. As one of the most important information carriers, English has become the most widely used language in various fields [1]. Chinese citizens' ability to effectively use English is vital for China to succeed in modernization and participation in international activities [2]. Hence, college English education in China is being put forward higher and more urgent requirements to meet the new challenges.

English is playing a crucial role in the country's economic modernization; it is also a determining factor for individual students' career development and academic success. However, the current setup of college English courses in China that often consists of Public English courses and Professional English courses is not preparing Chinese students for their career development and academic success at a satisfactory level [3].
Therefore, this study aimed at investigating the problems of the setup of college English courses to provide practical recommendations for policymakers and university administrations to design appropriate English courses that could prepare college students with English proficiency to meet the new international challenges.

\section{CHINESE COLLEGE ENGLISH EDUCATION SYSTEM}

Chinese College English Education often has two components: (1) Public English course for all majors in the first two years of the college education; and (2) Professional English courses for particular majors (e.g., Engineering) starting the third semester. Often, Public English course teaches structural/grammatical elements of English language and language skills to help students pass the exams and communicate in academic settings 
[4]. In contrast, Public English course is set up to prepare students to communicate successfully in their major-oriented professional activities (e.g., read academic papers, present at academic conferences, networking with experts in their professions worldwide [5]).

Other phrases have been used in the literature by Chinese scholars to describe the public English and professional English course in China. For example:

EGP: English for General Purposes

EAP: English for Academic Purposes

ESP: English for Specific Purposes

College English Course: the courses set up for non-English major students

However, we believe that those terms are mostly taken directly from scholarship outside China and not authentically reflect the nature of Chinese college English education courses. For this study, we will use the term - "Major-oriented English Course" to describe an adopted college-level educational model we propose in this study. We define the Major-oriented English course as a type of course that combines the public English course with the professional English course, by integrating professional knowledge into English teaching materials to better equip Chinese college students with basic English skills and profession-related English knowledge.

\section{LITERATURE REVIEW}

\subsection{The Significance of Public English courses}

English education is now encountering fast and significant change. The requirement for Chinese students' language proficiency in English becomes significantly higher, particularly in light of the challenges posed by economic globalization [6]. Also, with the rapid development of China's economy, the economic and cultural exchanges between China and other countries across the world increase. These changes that are happening present new challenges to Chinese College English education. Hence, colleges and universities must provide more practical and wellstructured English courses to improve student's overall English proficiency [7].

\subsubsection{Student Attitude toward Public English Courses}

Attitude is one critical factor that could influence students' English learning [8]. Previous studies (e.g., [9]) found out that college students often lack a good learning attitude toward public English courses; few students make good use of their English teachers' learning materials left after class. Lu [10] specifically pointed out most non-English majors attend public English courses to pass the final exam or CET Band 4 or Band 6 (CET = College English Test). However, taking the courses for passing CET Band 4 or 6 or the final exams is not enough to develop English proficiency for the courses' purpose. Zhang and Li [11] concluded that most students could easily pass the test as long as they review the textbook before the final exam.

\subsubsection{Public English teacher's English skills and Teaching Practices}

The overall quality of Chinese college English teaching is generally not high enough [9] due to a historical shortage of qualified teachers. Specifically, many public English teachers often overly rely on multimedia tools [7]. At the same time, some are resistant to the multimedia approach and thus still take traditional teaching methods (e.g., blackboard writing, textbook reading).

Moreover, many public English teachers were observed to still employed the authoritative teaching approach with little to no consideration for student perspectives and voices [10]. What's even more concerning is that nearly $70 \%$ of college English teachers admitted that they are still using the GrammarTranslation teaching method in their English teaching, which deprives students' opportunities to use English and think independently in class [12].

\subsubsection{Public English courses' teaching materials}

Nearly all colleges in China must use the same textbook that includes outdated, non-interactive, and CET-targeted $($ CET $=$ College English Test $)$ teaching contents. It further encourages students' attending the courses to pass exams instead of applying knowledge to professional research and future work [7]. Public English teachers were also found to emphasize text analyzing and vocabulary teaching while neglecting the training of students' practical competence in using the language [7]. Zhang and $\mathrm{Li}$ [11] pointed out that the current teaching content in Public English course consumes students' learning passion. That is because the knowledge students learned in the class cannot be applied to daily communication or professional study, especially for the grammar knowledge they have already taught repeatedly in high school.

\subsection{The Significance of Professional English courses}

Various majors often require high English proficiency in professional English [13]. In emerging and interdisciplinary fields, it is widely expected for college graduates to read professional literature and have preliminary language communication ability to 
catch up with the progress of advanced world technology and foreign professional development trends. Moreover, the new challenge for college students is not only reading but also writing technical documents. The development of globalization in English indicated that the future goal of English learning is to educate students to be global citizens [14]. Thus, the purpose of College English courses, specifically professional English courses, should no longer be the acquisition of the language but be the practical functionality.

\subsubsection{The Problems of Professional English Courses}

The content taught in Professional English Course often lacked coherence and systematization [15]. Specifically, Cai [16] stated that professional English teaching in China often attempted to adopt English as the instructional medium to teaching Professional English, but it failed. Those materials used failed to meet the criteria of qualified Professional English materials that attract students' attention and show the systematization of teaching.

Furthermore, Yang W.H. and Xu T. [13] stated that professional English courses were usually arranged in the third school semester. At that time, most of the professional courses have not yet begun. Therefore, students have not acquired sufficient professional knowledge. Under such circumstances, understanding may be difficult for them.

Additionally, the teaching practices in Professional English courses are mostly similar to those in Public English courses. Teachers of professional English courses often solely read the new words and phrases, explained the meaning of the text sentence by sentence, and left sometime in the end for the students to reflect on what they have learned [13]. Teaching content is also nothing more than vocabulary and sentences (citation). Students' interests in learning professional English are most likely to be low with such problematic teaching practices.

\subsubsection{Recommendations for Professional English teaching}

Literature on English teaching has provided various recommendations on improving professional English teaching in college English education in China. Wang L.J. [15] pointed out that teaching professional English courses is one way to teach Professional English. The teaching goal of such courses is to improve students' language proficiency and impart professional knowledge. However, the success of these kinds of courses depends on the English proficiency of both students and teachers.
Moreover, reforming teaching methods and stimulating students' interests in learning are also considered necessary. Yang W.H. and $\mathrm{Xu}$ T. [13] suggested that the innovation of professional English courses requires teachers to select teaching materials in close relation to students' majors. According to Lew is, M. and Hill, J [17], appropriate teaching materials for professional English courses need to meet the following four criteria: 1) stimulate students' interest; 2) majorrelated; 3) Interesting; and 4) consists of meaningful activities. Also, teachers should incorporate multimedia text forms more into their teaching.

Additionally, the reform of teaching methods should focus on shifting the roles of students in learning. In the past, students were often passive learners or supporting participators. However, Yang W.H. and Xu T. [13] indicated that students should take the initiative in learning. For example, teachers could consider shifting a traditional teacher-led lecture into a student-led seminar. Students could then take the lead in the decision-making of class content, materials, and delivery methods and thus develop ownership in learning.

\section{METHODS}

This study is an exploratory case study that investigates the problems of the setup of college English courses to provide practical recommendations for policymakers and university administrations to design appropriate English courses. Those could prepare college students with English proficiency to meet the new international challenges. A convenient sampling strategy was purposefully chosen to recruit participants at the universities the authors currently located. A total of 10 participants from various majors (e.g., Medicine, Accounting, Chemistry) agreed to participate in this study. At the time of the data collection, the participants have already taken both the Public English courses and the Professional English courses. Table 1 demonstrates the detailed participant information.

TABLE 1. Participant Information

\begin{tabular}{llll}
\hline $\begin{array}{l}\text { Participant } \\
\text { (pseudonym) }\end{array}$ & Major & Age & $\begin{array}{l}\text { Grade } \\
\text { Level }\end{array}$ \\
\hline David Feng & E-commerce & 23 & $\begin{array}{l}\text { Senior } \\
\text { Year }\end{array}$ \\
Irene & Medicine & 23 & $\begin{array}{l}\text { Senior } \\
\text { Year }\end{array}$ \\
Nancy Hui & Chinese Traditional & 22 & $\begin{array}{l}\text { Junior } \\
\text { Year }\end{array}$ \\
& Medicine & & Junior \\
Lucy Zhang & Accounting & 22 & Year \\
& & &
\end{tabular}




\begin{tabular}{llll}
\hline Yuki Wang & Accounting & 23 & $\begin{array}{l}\text { Senior } \\
\text { Year }\end{array}$ \\
Jack Li & Chemistry & 22 & $\begin{array}{l}\text { Junior } \\
\text { Year }\end{array}$ \\
Alex Wei & Civil Engineering & 23 & $\begin{array}{l}\text { Senior } \\
\text { Year }\end{array}$ \\
Jackson & Computer & 22 & $\begin{array}{l}\text { Junior } \\
\text { Year }\end{array}$ \\
Monica & International Trade & 23 & $\begin{array}{l}\text { Senior } \\
\text { Year }\end{array}$ \\
Deng & Biomedical & 23 & Senior \\
Daniel Xu & Engineering & & Year \\
\hline
\end{tabular}

A Focus group interview was conducted to collect data for this study. A total of 17 questions were asked to prompt the participants to discuss their perceptions of the Public English courses and the Professional English courses. The focus group was conducted in May 2021 and was recorded for data analysis purposes. Inductive coding was applied to code the recorded focus group interview, and the codes were grouped and categorized for theme development.

\section{FINDINGS}

\subsection{Public English}

\subsubsection{Exam-Oriented Public English Course}

During our in-depth interview, students generally considered that their Public English classes are specifically set up to help them pass CET4 and CET6 (China's College English Test). For example, Yuki Wang (pseudonym) from accounting major mentioned that:

"During our English public class, key vocabularies from the CET will be emphasized from time to time by our teacher, while exercises from previous tests will be left as homework to guarantee us to pass the exams."

CET-related knowledge, concepts, and vocabularies are emphasized in the public English classes, passing CET is often required for graduation in most universities in China. From civil engineering major, Alex Wei (pseudonym) said, "in my colleges, certificates of CET4/6 is the threshold of graduation." Requiring the passing of CET for graduation would be likely to lower students' motivation in English learning. For example, one active interviewee, David Feng (pseudonym) from E-commerce major mentioned that:

"He only recognizes Public English classes as a tool in passing CET4/6 and once he passes the CET, he will free himself from attending the courses for it is boring and no longer worthwhile."

As a result, learning English is no longer the motivation for students to take Public English courses. Some students only take Public English courses because they are required to take them. For example, Lucy Zhang (pseudonym) from accounting major put it bluntly: "I take the course only because it is a compulsory one and I need to have it to earn credits." When discussing why she losses interests in the Public English class, she further elaborated that:

"The exam is easy to pass since our teacher will always emphasize key points that are going to occur in the final test. So basically, you can pass the final exam as long as you can memorize those key points."

Likewise, one computer major student added: "our Public English class is boring because our teacher put too much emphasis on CET4 training. When the test is coming, we are required to put textbooks aside and study CET only."

To conclude, participants of this study considered that most Public English courses in China are still oriented around CET tests or college final exams. At the same time, few of them managed to raise students' learning interests in English. Hence, it is essential to change the college Public English course orientation by playing down the significance of exams to boost students' English learning interests.

\subsubsection{Public English teachers' Poor English Skills and Outdated Teaching Materials/Approaches}

When interviewees are asked to evaluate their Public English course teachers, medical students Irene said:

“Our English teachers' pronunciation and accent is strange, which makes it difficult for me to understand her teaching contents. Even worse, one senior Public English teacher always uses her old slides with outdated teaching materials on."

However, Jack Li from Chemistry major claimed that his English teacher is humorous and interesting, making her English class quite popular in the year. He added: “So, I reckon teachers' English proficiency can draw a great influence on students' enthusiasms during English classes."

Lucy Zhang, a student majors in accounting, believes Public English classes are boring and not helpful in developing her English proficiency since the English teacher employs the same teaching method in every class:

"Every Public English class is the same, which starts with students' oral presentation, followed by dialogue 
roleplays and group discussion. Most of my classmates will do other things instead of paying attention to what presenters are talking about during the oral presentation session. Likewise, few people will participate in dialogue roleplays and group discussions except for several active ones."

To sum up, interviewees of the study generally believed that English teachers' English proficiency had affected their understanding and learning of English. Also, teaching methods employed in some Public English classes are rigid and onefold, neglecting students who are shy to express themselves in front of the whole class and overestimating some students' learning initiatives. Therefore, it seems imperative for Public English teachers to improve their English skills, diversify their teaching approaches, and make English teaching-learning more appealing.

\subsubsection{Public English Courses' Problematic Focus}

In terms of the teaching content, Monica Deng from International Trade major said: "I think our public English classes lay too much emphasis on reading and writing while neglecting the training of speaking and listening." Lucy Zhang added to her opinion by saying

" Our English teachers spend too much time on vocabulary teaching and dictation, so we get bored very easily.”

As for students with good English proficiency, David Feng claimed that the reason why he lost interest in college English class is that the teaching content is too easy for him since he has already grasped basic English knowledge before entering the university:

"It's a waste of time to study the basic grammar and vocabularies that I have already grasped again, so I always study other subjects in the Public English class."

Lucy Zhang agreed with David and said: “The quantity of new knowledge taught in class is rather small, so I rather learn English by myself through taking some online courses to improve my learning efficiency.

However, Daniel Xu, from Biomedical Engineering major, and Jack Li, from Chemistry major, both find a selective course called English Listening and Speaking in their colleges more practical and fascinating compared with the Public English course. According to Daniel, "The contents taught in that course are more interesting and useful.”

Thus, considering the feedback from our participants, the teaching content of public English courses needs to be adjusted according to students' real needs. Otherwise, students may easily lose their interest and gain nothing from the course.

\subsection{Professional English}

\subsubsection{The Need for Professional English Courses}

The participants widely acknowledged that professional English was significant, which could boost their major study. Since western countries take the lead in advanced high-technology areas, students in these majors have to read many English writings and absorb new western ideas to follow the new academic trend. For example, Nancy Hui from Traditional Chinese Medicine major mentioned that:

"To finish some of my essays, I have to read a large number of English writings to learn some new medicine theories." It is shown that professional English plays an essential role in students' major studies. Moreover, some students presented that professional English laid a solid foundation for their academic research, as their research includes many professional vocabularies and abbreviations with which they are unfamiliar. For example, Jack Li said that: "When I was doing my research with my supervisor, I found that it was difficult for me to read major-related materials fluently as it concluded complicated professional words.” Nancy Hui added to her perspective by saying that:

"One-year professional English courses assist me in understanding literature better as I have learned the word-formation of proper nouns, prefixes, and suffixes which help me infer the meaning of professional words and phrases."

It is mostly showed that excellent mastery of professional English could facilitate students' academic research. Furthermore, proficiency in professional English could make their research presentation fluent and clear, which helps them show their academic results comprehensively. For example, Lucy Zhang mentioned that:

"Professional English did help me in my last-year final presentation. When I presented the SWOT analysis, cash flow statement, consolidated balance sheet, and so on, which consist of many professional English, my mastery of professional English facilitated me. As I have learned it in my ACCA courses, I did a good job and had a good score."

In addition, it is also believed that professional English would help students in the academic area and make them more competitive in their future job hunting. David mentioned that:

"If they wanted to enter a foreign company or a large private company where the working system and official documents are all presented in English, a strong quality of professional English was indispensable."

Owing to this, good proficiency in professional English seems to be a necessity. 
In conclusion, it is essential to attend professional English courses in universities to help students prepare better for future academic research and job hunting.

\subsubsection{Problems of Professional English Courses}

Professional English knowledge can help prepare students for their future careers. However, the participants also consider that the curriculum of professional English is not well-developed, which reflects in the time and duration allocated for professional English courses and the course content. First of all, most professional English courses are only offered for one semester. Students had very few opportunities to practice and apply the knowledge after the end of the course. For example, Irene said that:

"The professional English course only lasted for one semester. Even though the knowledge did benefit me, I forgot them so fast that I could not recall what I learned after a few months."

Thus, learning professional knowledge became useless, which failed to boost their future careers and academic research proficiency. Furthermore, most professional English teachers were not able to use English efficiently in class. English was only used to show words on the PowerPoint, not as the communication language in class. For example, Yuki Wang shared that: "My professional English teacher only showed the words and phrases on the screen and taught us the meaning of them." Nancy Hui added to her perspective by saying that: "My teacher always presented the whole class in Chinese instead of English." Owing to this, those students thought professional English courses are not so attractive for them. Moreover, teaching content was boring too. Most professional English classes consisted of mechanical teaching of vocabulary and phrases, so many students were not interested in learning professional English and refused to learn it in depth. For example, Lucy Zhang from the major of accounting said that: "The majority of the English professional class is about financial vocabulary, and there was no teaching about passages or materials." Because of this, the learning of professional English did not cover reading, listening, talking parts, which failed to satisfy students' needs in future career and academic development.

Thus, the curriculum of professional English courses should focus on meeting the students' needs better. For example, students could start to learn professional English in their sophomore year, and the course should last for at least two years to let students fully grasp professional English. Additionally, teachers should use English effectively and appropriately in the classroom, teaching words and phrases and professional articles as teaching materials. In this way, students can grasp professional knowledge better.

\subsubsection{Professional English Courses not Necessary for Some Students}

Professional English is not considered necessary for some students who decided to divert to other fields in their future work. Once they determined their minds to change their future field, they had to learn up-to-date knowledge related to their future field. For example, Yuki Wang majored in accounting mentioned that: "I wanted to divert her major to human resources in her postgraduate degree, so I had to update my knowledge and learn more about my new major." Owing to this, what they learned from former specialized courses as well as professional English was deserted. Learning professional English seemed to be a waste of time. Additionally, Students who entered a state-owned enterprise after graduation had few opportunities to use professional English in their daily work. For example, Lucy Zhang, who once had an internship in a stateowned enterprise for one month, mentioned that: "In my daily work, I hardly use English." Their working system was also Chinese, where there was no need to master professional English.

Owing to this, students who want to change their major field after graduation prefer a new kind of English class, improving their English proficiency directly. However, most of them reckoned that Public English teaching failed to meet their needs. Thus, a new effective way to teach English in universities should be proposed.

\subsubsection{Suggestions for College English Course}

When it comes to the question "What kind of Public English or Professional English course do you want to take? Irene said that:

"For our medical students, we are always required to read medical journals that are mostly written in English after class. So instead of using those poor-structured and outdated textbooks, why don't we study English medical journals directly in both Public English and professional English class?"

Yuki Wang added her opinions by saying that:

"I reckon that this kind of teaching material could also improve our English writing that is severely overlooked in current college English courses."

While Lucy Zhang added:

"I think Public English course and Professional English course can be merged into one course thus students can learn specialized vocabularies and basic grammar points at the same time." Irene agreed with her by saying that: "in this way, I believe the teaching content in English class will be more comprehensive and we students will be more enthusiastic." However, 
David stressed: "Teachers who are responsible for compilating teaching material should pay more attention to integrating professional knowledge into English teaching, which means the teaching content should neither be too difficult nor too simple."

To conclude, participants of this study considered that integrating a Public English course with a Professional English course might be a possible way to boost students' enthusiasm in college English courses. But the compilation of teaching materials should be handled carefully.

\section{SUGGESTIONS AND STRATEGIES}

Through research and interviews, the main problems that college English education faces are: English learning initiative, the attractiveness of teaching methods and course contents, teachers' English proficiency. The following strategies are proposed to boost students' enthusiasm towards college English courses and improve their overall English proficiency.

\subsection{Introduce Major-oriented English Course to College English Education}

Based on our in-depth interviews with college students from different majors, it can be seen that both the Public English course and Professional English course have downsides. The two courses are built up rather independently but correlated which caused a series of problems such as the repetition of teaching content and unreasonable opening span. Hence, to improve college students' overall English proficiency, we should simultaneously advance the Public English course and Professional English course. The study participants deem the college English course should merge the Public English course and the Professional English course to create a Major-oriented English course. Professional-related English materials will be tailored customized into teaching content to train students' basic English abilities in this course. Thus, students can be motivated and implement what they learned in professional courses into practical English learning.

\section{CONCLUSION}

The paper has sought to explore and address problems relating to college English teaching, conducted from the aspect of the Public English course and professional English course. In the study, we have proposed that it might be applicable and effective to create a brand-new Major-oriented English course through integrating professional-based English materials into daily English teaching contents and practices to promote college students' English learning enthusiasm and learning efficacy. However, the feasibility and effectiveness of the proposed Major-oriented course are yet to examine, which can be a topic for future English teaching research.

\section{ACKNOWLEDGMENT}

We would like to thank all the STEM college students who agreed to participate in our study.

\section{REFERENCES}

[1] Zhang Wenxia, and Luo Lisheng, "Thoughts on the Current Situation and Development of College English Teaching," Foreign Language World, Shanghai, vol. 101, pp. 32-39, 2004.

[2] $\mathrm{Hu}$ Guangwei, "Reforms of Basic EnglishLanguage Education in China: An Overview," International Journal of Educational Reform, vol. 14, no. 2, April. 2005, pp. 140-165 doi:10.1177/105678790501400202.

[3] Liu Haiying, "Practical English Teaching Model: Profession-based Teaching Model for the Cultivation of Practical Talents," Journal of Chongqing University of Arts and Sciences (Social Sciences Edition), vol.29, no.5, September. 2010, pp. 186-190.

[4] T. Hutchinson, and A. Waters, "English for Specific Purpose, A Learning Centred Approach," Cambridge University Press, Cambridge. pp. 183, 1987.

[5] D. E. Tony, and S. J. Maggie, "Developments in English for specific purposes: a multi-disciplinary approach," Cambridge University Press, Cambridge, pp. 297-300, 1998.

[6] Spring, M. K., "Languages for Specific Purposes Curriculum in the Context of Chinese-Language Flagship Programs," Modern Language Journal, vol. 96 no. s1, pp. 140-157, January 2012.

[7] $\mathrm{Xu}$ Lin,"Current English Education Reform in China," Journal of Kaifeng Institute of Eduacation, vol. 33, no. 7, pp. 106-107, November 2013.

[8] Ooi, C. L. and A. Yahaya, "Factors contributing to proficiency in English as a second language among Chinese students in Johor Bahru," Elixir Psychology, vol. 41, pp. 5837-5848, 2008.

[9] Guo Lijie, and Jin, Yue, "On Reflections and Suggestions to the College English Teaching after the Reform," Journal of Higher Education, vol. 8, pp. 123-124, 2017.

[10] Lu Mimi, "On the Current Situation, Problems and Countermeasures of College English Teaching in 
China," Course Education Research, vol. 14, pp. 124-125, 2019.

[11] Zhang Xi, and Li Yanlin, "Research on the Reform of College English Teaching for Non-English Majors," Theory and Practice of Ccontemporary Education, vol. 7, no. 3, pp. 116-118, March, 2015.

[12] Guo Linke, "Analysis on the Current Situation, Problems and Countermeasures of College English Teaching in China," Science \& Technology Information, vol. 21, pp. 245-255, 2010.

[13] Yang Weihua and Xu Tao, "Reflections on the reform of Professional English," in Journal of Hebei Institute of Architectural Science and Technology, vol.21. Hebei: Academic, 2004, pp. 79-80.
[14] Zou Wenli, "The practice of professional English education in higher education in Taiwan -- Taking the Professional English Course of Chenggong University as an Example, " in Foreign Language Teaching Theory and Practice, 2013, pp. 12-16.

[15] Wang Lijuan, "Present situation, application and prospect of ESP teaching in colleges," in Foreign Language Education, vol.35. Nanchang: Academic, 2014, pp. 59-63.

[16] Cai Jikang, "The influence of Professional English and its textbooks on ESP teaching in colleges in China," in Foreign Language and Their Teaching, vol, 269, 2013, pp. 1-4.

[17] M. Lewis, \& J. Hill, Source Book for Teaching English as a Foreign Language. Hong Kong: Macmillan Publishers Limited, 2003. 